\title{
Different true-protein sources do not modify the metabolism of crossbred Bos taurus $\times$ Bos indicus growing heifers
}

\section{Diego Azevedo Mota ${ }^{1}$, Juliana Duarte Messana ${ }^{2}$, Roberta Carrilho Canesin², Giovani Fiorentini ${ }^{2}$, Alexandre Vaz Pires ${ }^{3}$, Telma Teresinha Berchielli2,4}

\author{
${ }^{1}$ Universidade Federal da Fronteira Sul, Campus Erechim, Erechim, RS, Brasil. \\ ${ }^{2}$ Universidade Estadual Paulista, Faculdade de Ciências Agrárias e Veterinárias, Departamento de Zootecnia, Jaboticabal, SP, Brasil. \\ ${ }^{3}$ Universidade de São Paulo, Escola Superior de Agricultura "Luiz de Queiroz", Departamento de Zootecnia, Piracicaba, SP, Brasil. \\ ${ }^{4}$ CNPq Researcher/Member of INCT-CA.
}

\begin{abstract}
The present study was conducted to investigate the effect of alternative true-protein sources to soybean meal, with different ruminal degradability, using a sugarcane-based diet, on nutrient digestion, ruminal fermentation, efficiency of microbial protein synthesis and passage rate in prepubertal dairy heifers. Eight crossbred rumen- and duodenum-cannulated Holstein $\times$ Gyr dairy heifers $(202.0 \pm 11.5 \mathrm{~kg} \mathrm{BW})$ were evaluated in a $4 \times 4$ Latin square experimental design with four treatments and four periods in two simultaneous replicates. Dietary treatments were: soybean meal; cottonseed meal; peanut meal; and sunflower meal. When associated with diets containing sugarcane, the different protein sources did not affect intake or digestibility of dry mater, crude protein, organic matter and neutral detergent fiber. The average ruminal $\mathrm{pH}, \mathrm{NH}_{3}-\mathrm{N}$ and concentration of total volatile fatty acids were not different among the diets supplied. The concentration of butyric acid was different among the protein sources, wherein the animals fed the diet with sunflower meal presented lower values than those fed the other sources. Diets did not affect nitrogen balance, microbial nitrogen, microbial synthesis efficiency, estimated dry matter flow, or passage rate. Alternative protein sources can be used to reduce the costs without changing the animal metabolism.
\end{abstract}

Key Words: microbial synthesis, nitrogen balance, rumen degradable protein, sugarcane

\section{Introduction}

The global food production is not growing at the appropriate rate to meet the estimated world needs until 2050 (Lal, 2013). The challenge of livestock production is to seek nutritional alternatives that increase the efficiency of the system, meeting the demand for lower-cost feeds. Optimizing animal performance based on native feeds is one of the main goals of livestock producers. However, the right understanding of the nutritional properties of these feeds is essential when aiming to reduce age at first calving. In tropical countries, heifer diets are mostly composed of roughages, in which sugarcane is very commonly used due to its higher productivity over the year. However, the low protein content of this roughage requires a supplemental protein source in the diet (Queiroz et al., 2012).

Choosing alternative sources of supplemental protein may lower the production costs but, on the other hand, the sources influence the amount of rumen undegradable protein

Received Received May 16, 2014 and accepted December 16, 2014 Corresponding author: duarte_juliana@hotmail.com

http://dx.doi.org/10.1590/S1806-92902015000200003

Copyright (C) 2015 Sociedade Brasileira de Zootecnia. This is an Open Access article distributed under the terms of the Creative Commons Attribution Non-Commercial License, which permits unrestricted non-commercial use, distribution, and reproduction in any medium, provided the original work is properly cited. and lead to an inappropriate supply of rumen degradable protein, which in turn could reduce the microbial protein synthesis, causing a change in the profile of absorbed amino acids (Wright et al., 2005; Brito et al., 2007; Broderick et al., 2007), which ultimately results in lower animal performance (Yang et al., 2010).

The theoretical concepts of the responses to the sources of rumen undegradable protein have been equivocal (Ipharraguerre and Clark, 2005), because not only the protein source, but also their association with carbohydrates may lead to imbalance, resulting in an inefficient use of nitrogen, which incurs energy costs to the animal metabolism for elimination of the excess (Reynolds, 2006) and, as a consequence, lower animal efficiency (Yang et al., 2010). An adequate feeding balance may also reduce the excretion of nutrient and manure, reducing the excessive release of ammonium compounds such as $\mathrm{N}\left(\mathrm{NH}_{4}^{+}\right)$, nitrate $\left(\mathrm{NO}_{3}^{-}\right)$, and nitrite $\left(\mathrm{NO}_{2}^{-}\right)$to the atmosphere or the soil, and resulting in lower environmental impact (Vasconcelos et al., 2007).

The hypothesis of the present study is that alternative true-protein sources to soybean meal with different ruminal degradability have been associated with changes in rumen fermentation, possibly affecting the intake and digestibility of the diet, while increasing the efficiency of microbial protein synthesis and reducing nitrogen losses. 
The present study was conducted to investigate the effect of alternative true-protein sources to soybean meal, with different ruminal degradability, in a sugarcane based diet, on nutrient digestion, ruminal fermentation, efficiency of microbial protein synthesis, passage flow and passage rate in prepubertal dairy heifers.

\section{Material and Methods}

The experiment was conducted in Brazil, at geographical coordinates $21^{\circ} 15^{\prime} 22^{\prime \prime}$ South latitude, $48^{\circ} 18^{\prime} 58^{\prime \prime}$ West longitude, and $595 \mathrm{~m}$ altitude. According to the Köppen classification, the climate in Jaboticabal city is a subtropical type Cwa, with rainy summers and dry winters. Research on animals was conducted according to the Institutional Committee on Animal Use (protocol number 022122/09).

Eight rumen- and duodenum-cannulated crossbred Holstein $\times$ Gyr dairy heifers $(202.0 \mathrm{BW} \pm 11.5 \mathrm{~kg})$ were evaluated in $4 \times 4$ Latin square experimental design with four treatments and four periods in two simultaneous replicates. The diets were formulated using the RLM/ Esalq-USP software (Lanna et al., 1999) in accordance with the Cornell Net Carbohydrate and Protein System
(CNCPS) developed by Fox et al. (2000). The roughage was sugarcane $(600 \mathrm{~g} / \mathrm{kg}$ on a DM basis and with the following composition: $279 \mathrm{~g} / \mathrm{kg} \mathrm{DM} ; 33.9 \mathrm{~g} / \mathrm{kg} \mathrm{CP} ; 566 \mathrm{~g} / \mathrm{kg}$ $\mathrm{NDF}$ ), and the concentrate ( $400 \mathrm{~g} / \mathrm{kg}$ on a DM basis) was composed of corn, concentrate protein, mineral supplement and urea (Table 1). The dietary treatments were: soybean meal, cottonseed meal, peanut meal, and sunflower meal.

The experimental period lasted $28 \mathrm{~d}$, with $10 \mathrm{~d}$ of diet adaptation and $18 \mathrm{~d}$ of sampling. On d 11 and 20, collections were made to study the passage rate and the adaptation of animals to external markers (complexed chrome (Cr-EDTA) and ytterbium chloride $\left(\mathrm{YbCl}_{3}\right)$. From d 21 to 28 , feces, urine and duodenal fluid were collected and ruminal fluid was sampled to estimate the ruminal $\mathrm{pH}$, volatile fatty acids (VFA) and ammonia $\mathrm{N}\left(\mathrm{NH}_{3}-\mathrm{N}\right)$.

Animals were kept in metabolism stalls equipped with individual feed bunks and water troughs during data collection. Due to the work routine in the experimental station, where the sugarcane was chopped once a day, at $07.00 \mathrm{~h}$, all animals received the roughage and approximately $50 \%$ of the concentrate, whereas in the afternoon (at $15.30 \mathrm{~h}$ ), the remainder of the concentrate was mixed to the feed present in the trough, as a strategy for animals to return to the trough and also to reduce the chances of diet fermentation.

Table 1 - Percentage of ingredients and chemical composition of diets

\begin{tabular}{|c|c|c|c|c|}
\hline & \multicolumn{4}{|c|}{ Diets } \\
\hline & SM & $\mathrm{CM}$ & PM & SUM \\
\hline \multicolumn{5}{|l|}{ Ingredient, $\mathrm{g} / \mathrm{kg} \mathrm{DM}$} \\
\hline Sugarcane & 600.00 & 600.00 & 600.00 & 600.00 \\
\hline Soybean meal & 150.00 & - & - & - \\
\hline Cottonseed meal & - & 150.00 & - & - \\
\hline Peanut meal & - & - & 148.00 & - \\
\hline Sunflower meal & - & - & - & 180.00 \\
\hline Ground corn & 233.50 & 235.00 & 233.00 & 200.00 \\
\hline Mineral supplement ${ }^{1}$ & 10.00 & 10.00 & 10.00 & 10.00 \\
\hline Urea & 6.50 & 5.00 & 9.00 & 10.00 \\
\hline \multicolumn{5}{|l|}{ Chemical composition } \\
\hline Dry matter, $\mathrm{g} / \mathrm{kg}$ & 535.00 & 537.00 & 535.00 & 538.00 \\
\hline Organic matter, $\mathrm{g} / \mathrm{kg} \mathrm{DM}$ & 966.00 & 965.00 & 967.00 & 968.00 \\
\hline Crude protein, g/kg DM & 135.00 & 133.00 & 133.00 & 131.00 \\
\hline Rumen degradable protein (RDP), g/kg DM & 92.80 & 91.60 & 78.60 & 74.80 \\
\hline Rumen undegradable protein (RUP), g/kg DM & 42.10 & 41.50 & 54.60 & 56.40 \\
\hline Ether extract, $g / \mathrm{kg} \mathrm{DM}$ & 11.10 & 9.90 & 9.00 & 8.00 \\
\hline Neutral detergent fiber, $\mathrm{g} / \mathrm{kg} \mathrm{DM}$ & 388.00 & 351.00 & 359.00 & 362.00 \\
\hline Acid detergent fiber, $\mathrm{g} / \mathrm{kg} \mathrm{DM}$ & 189.00 & 189.00 & 195.00 & 200.00 \\
\hline Lignin, g/kg DM & 20.10 & 27.80 & 22.30 & 21.70 \\
\hline Non-fibrous carbohydrate ${ }^{2}, \mathrm{~g} / \mathrm{kg}$ DM & 431.00 & 436.00 & 403.00 & 395.00 \\
\hline Total carbohydrate ${ }^{2}, \mathrm{~g} / \mathrm{kg} \mathrm{DM}$ & 819.00 & 821.00 & 822.00 & 826.00 \\
\hline Total digestible nutrients, $\mathrm{g} / \mathrm{kg} \mathrm{DM}$ & 684.00 & 634.00 & 643.00 & 617.00 \\
\hline Metabolizable energy (ME), Mcal/kg & 2.47 & 2.29 & 2.32 & 2.23 \\
\hline $\mathrm{RDP}: \mathrm{ME}$ ratio, g/Mcal & 37.60 & 40.00 & 33.90 & 33.50 \\
\hline
\end{tabular}

$\mathrm{SM}$ - containing $600 \mathrm{~g} / \mathrm{kg}$ of sugarcane and $400 \mathrm{~g} / \mathrm{kg}$ of concentrate based on soybean meal; $\mathrm{CM}$ - containing $600 \mathrm{~g} / \mathrm{kg}$ of sugarcane and $400 \mathrm{~g} / \mathrm{kg}$ of concentrate based on cottonseed meal; PM - containing $600 \mathrm{~g} / \mathrm{kg}$ of sugarcane and $400 \mathrm{~g} / \mathrm{kg}$ of concentrate based on peanut meal; SUM - containing $600 \mathrm{~g} / \mathrm{kg}$ of sugarcane and $400 \mathrm{~g} / \mathrm{kg}$ of concentrate based on sunflower meal.

${ }^{1}$ Composition of the mineral mixture (Ca - 146 g; P - 40 g; Mg - 20 g; S - 40 g; Na - 56 g; Cu - 350 g; Mn - 900 mg; Zi - 1,300 mg; I - 24 mg; Co - 10 mg; Se - 10 mg; F (max.) - 400 mg; Monensin - $670 \mathrm{mg})$.

${ }^{2}$ Calculated values (Sniffen et al., 1992). 
No fermentation of sugarcane was observed in the trough, during the experiment. Throughout the entire experimental period, quantities were adjusted to allow for approximately $100 \mathrm{~g} / \mathrm{kg}$ surplus in relation to the total consumed the previous day. Feed refusals were collected and weighed before feeding, and sub samples were obtained and frozen at $-20^{\circ} \mathrm{C}$ for later analysis.

Fiber-mordant ytterbium acetate was used to estimate the passage rate of the fiber fraction of the diet, as described by Uden et al. (1980), with some modifications. Fifty grams of sugarcane-mordant with ytterbium acetate $\left(\mathrm{YbCl}_{3}\right)$ were provided to the animals in a single dose directly into the rumen in the morning of the 10th experimental day, and fecal collection was performed indicating time zero of the fecal excretion curve. Later, feces were collected at times 9, $24,33,48,57,72,81,96,105$ and $120 \mathrm{~h}$ after the marker administration (11 th to 15 th day). The samples were collected directly from the rectum of animals. The compartment model was used to calculate the passage rate and retention time of sugarcane, as described by Czerkawski (1986).

The total fecal collection was used to determine the apparent digestibility. Feces were removed from trays daily at $08.00 \mathrm{~h}$, then weighed, and homogenized; samples of approximately $500 \mathrm{~g}$ were taken for each animal, placed into plastic bags and frozen, and a composite sample was prepared for each animal based on the air-dry weight. Duodenal samples were collected over two days (fourth and fifth data-collection days during the study period) at 6-h intervals. The sample collection during the second day was delayed to ensure that every $3 \mathrm{~h}$ in a $24 \mathrm{~h}$ period was properly represented (Oliveira et al., 2007). Samples were kept at $-10{ }^{\circ} \mathrm{C}$, and at the end of the period, one sample was made by pooling the samples of each animal in each period. Samples of feces and duodenal contents were dried in a forced-ventilation oven at $55^{\circ} \mathrm{C}$ for $72 \mathrm{~h}$ and ground in a mill with 1-mm-mesh sieve. Cr-EDTA was used as a fluidphase marker and $\mathrm{YbCl}_{3}$ was used as a solid-phase marker at the estimate of the daily DM flows in the duodenum, as described by Faichney (1975). After associating the values of flow and fecal dry matter, partial digestibility coefficients (post-rumen and ruminal) were calculated according to Ahvenjärvi et al. (2003).

Total urine collections were performed for five days in the experimental period with two-way Foley catheters, 22 or $26 \mathrm{Fr}$ with 30 or $60 \mathrm{~mL}$ balloon, respectively, according to the size of the heifers. A polyethylene tube was adapted at the free end of the probe for the urine to be conducted to lidded plastic containers containing $500 \mathrm{~mL}$ sulfuric acid $200 \mathrm{~mL} / \mathrm{L}$. At the end of each 24-hour collection period, the total weight of the homogenized content of the container was determined. Aliquots of approximately $200 \mathrm{~mL}$ undiluted urine from each animal were stored daily in a $1 \mathrm{~L}$ container at $-20^{\circ} \mathrm{C}$ for subsequent analyses to determine the nitrogen balance.

Ruminal contents were sampled on the twenty-sixth day of each sampling period to determine the $\mathrm{pH}$ values and the concentrations of VFA and $\mathrm{NH}_{3}-\mathrm{N}$. Rumen-fluid samples (around $80 \mathrm{~mL}$ ) were collected manually, both before supplying the diet (time zero) and 2, 4, 6, 8, 10, 12 , and $14 \mathrm{~h}$ after feeding. Immediately after collection, the $\mathrm{pH}$ of rumen fluid was determined using a digital potentiometer (ORION 710A, Boston, MA). A 20-mL aliquot of collected fluid was placed into a plastic bottle and frozen at $-20{ }^{\circ} \mathrm{C}$ for subsequent volatile fatty acid (VFA) analysis according to a method adapted from Erwin et al. (1961). A 40-mL aliquot of rumen fluid was used for ammonia $\mathrm{N}\left(\mathrm{NH}_{3}-\mathrm{N}\right)$ analysis, following the methodology adapted by Fenner (1965).

To determine the microbial composition and the microbial DM flow in the rumen, rumen fluid was collected $4 \mathrm{~h}$ after feeding on the 28nd day of each experimental period. Approximately $3.0 \mathrm{~L}$ of solid and liquid rumen digesta were collected from each animal and manually homogenized with $1.0 \mathrm{~L}$ of $1 \mathrm{~N}$ saline solution. Subsequently, the mixture was filtered through double-cotton fabric, generating approximately 2.0-L fluid samples; these were then stored in plastic containers with screw on lids and frozen at $-10{ }^{\circ} \mathrm{C}$. To isolate the bacteria from rumen digesta samples, differential centrifugation procedures were followed according to the methodology cited by Cecava et al. (1990). After isolation, the samples were freeze-dried and subjected to DM, ash, and total $\mathrm{N}$ estimation (AOAC, 1990). To estimate the biomass of microorganisms in rumen fluid and duodenal digesta samples, purine bases were used as microbial markers and quantified as described by Ushida et al. (1985).

Feed supplied, feed refusals, feces and duodenal samples were dried at $55^{\circ} \mathrm{C}$ for $72 \mathrm{~h}$ and ground in a Wiley mill (Thomas Scientific, Swedesboro, NJ) to pass through a $1 \mathrm{~mm}$ screen. Samples of corn silage, concentrates and feed refusals were analyzed for dry matter (DM; Association of Official Agricultural Chemists [AOAC] Official Method 934.01), ash (AOAC Official Method 942.05) and ether extract (EE; AOAC Official Method 920.39) contents, in accordance with the AOAC (1990). Nitrogen was determined using a LECO FP-528 nitrogen analyzer (LECO Corp., St. Joseph, MI).

Neutral detergent fiber was determined using $\alpha$-amylase and without the addition of sodium sulfite and according to Van Soest et al. (1991), adapted for an Ankom ${ }^{200}$ Fiber 
Analyzer (Ankom Technology, Fairport, NY). Acid detergent fiber was determined using the method described by Goering and Van Soest (1970), adapted for an Ankom ${ }^{200}$ Fiber Analyzer (Ankom Technology, Fairport, NY).

The intake, digestibility, passage rate and $\mathrm{N}$ balance data were analyzed as $4 \times 4$ Latin square design using the PROC MIXED procedure of SAS (Statistical Analysis System, version 9.2). The general mathematical model was represented as follows:

$$
Y_{i j k}=\mu+\alpha_{i}+\beta_{j}+h_{k}+\alpha \beta_{i j}+e_{i j k}
$$

in which $Y_{i j k}$ represents the observation on heifers $k$ given treatment $i$ at period $j ; \alpha_{i}$ represents the fixed effect of the $i$-th treatment, $i=1,2, \ldots, n_{t} ; \beta_{j}$ represents the fixed effect of the $j$-th period, $j=1,2, \ldots, n_{p}$; and $h_{k}$ represents the random effect of the $k$-th heifers, $k=1,2, \ldots, n_{h}$, with variance component $\sigma_{c}^{2}$ (Tempelman, 2004).

Ruminal $\mathrm{pH}, \mathrm{NH}_{3}-\mathrm{N}$ and VFA data were analyzed as a double $4 \times 4$ Latin square design with repeated measures over time using the PROC MIXED procedure of SAS (Statistical Analysis System, version 9.2). The model included the fixed effect of treatment, time, treatment $x$ time interaction, and random effects of animal and period. The structure of errors that best fitted the data according to the Bayesian information criterion (BIC) was used. Differences between treatment means were determined by Tukey's test. Differences among means with $\mathrm{P}<0.05$ were accepted as representing statistically significant differences.

\section{Results}

In this study it was observed that different protein sources, associated with diets containing sugarcane, do not affect intake or digestibility of dry matter, crude protein, organic matter and neutral detergent fiber $(\mathrm{P}>0.05$, Table 2$)$.

No interaction was observed between the times and diets for any of the studied ruminal parameters $(\mathrm{P}>0.05$; Table 3). The mean ruminal $\mathrm{pH}$ and $\mathrm{NH}_{3}-\mathrm{N}$ values were not different $(\mathrm{P}>0.05)$ among the diets supplied. However, differences in mean ruminal $\mathrm{pH}$ and $\mathrm{NH}_{3}-\mathrm{N}$ values were observed in times of collection $(\mathrm{P}<0.05)$. At the time of $10 \mathrm{~h}$ after the first feeding the concentration of $\mathrm{NH}_{3}-\mathrm{N}$ was lower $(\mathrm{P}<0.05)$ than times 1 and $2 \mathrm{~h}$, which showed highest values for this parameter. The ruminal $\mathrm{pH}$ decreased $(\mathrm{P}<0.05)$ from $4 \mathrm{~h}$ after the first feeding, as compared with times 0,1 and $2 \mathrm{~h}$. Furthermore, it was observed that the values obtained in the times of 10 and $12 \mathrm{~h}$ after the first feeding were statistically lower than the other collection times.

The concentration of total volatile fatty acids and acetic acid, propionic acid and the acetic:propionic acid ratio were not affected by the different protein sources (Table 3). The concentration of butyric acid showed differences according to the protein sources $(\mathrm{P}<0.001)$, in which the animals that received the diet with sunflower meal exhibited lower mean values than those fed the other sources.

The protein sources with different rumen degradability did not affect the nitrogen balance, microbial synthesis efficiency ( $\mathrm{g}$ micP/kg TDN) or ruminal kinetics $(\mathrm{P}>0.05$, Table 4).

\section{Discussion}

Systems of evaluation of food proteins have been developed to improve the accuracy of the protein in

Table 2 - Effect of dietary source of protein (soybean meal (SM), cottonseed meal (CM), peanut meal (PM) and sunflower meal (SUM)) on intake and digestibility in crossbred Holstein $\times$ Gyr dairy heifers

\begin{tabular}{|c|c|c|c|c|c|c|}
\hline & \multicolumn{4}{|c|}{ Diets } & \multirow{2}{*}{ SEM } & \multirow{2}{*}{ P-value } \\
\hline & SM & $\mathrm{CM}$ & PM & SUM & & \\
\hline \multicolumn{7}{|l|}{ Intake, $\mathrm{kg} / \mathrm{d}$} \\
\hline Dry matter & 5.18 & 5.11 & 5.21 & 5.02 & 0.444 & 0.735 \\
\hline Organic matter & 4.52 & 4.44 & 4.55 & 4.36 & 0.397 & 0.783 \\
\hline Crude protein & 0.65 & 0.63 & 0.65 & 0.62 & 0.058 & 0.727 \\
\hline Neutral detergent fiber & 1.87 & 1.83 & 1.86 & 1.88 & 0.230 & 0.734 \\
\hline \multicolumn{7}{|c|}{ Total apparent digestibility, $\mathrm{kg} / \mathrm{kg}$} \\
\hline Dry matter & 0.66 & 0.67 & 0.67 & 0.64 & 0.555 & 0.283 \\
\hline Organic matter & 0.70 & 0.68 & 0.68 & 0.67 & 0.782 & 0.593 \\
\hline Crude protein & 0.77 & 0.76 & 0.72 & 0.77 & 0.567 & 0.299 \\
\hline Neutral detergent fiber & 0.52 & 0.52 & 0.52 & 0.50 & 0.821 & 0.327 \\
\hline \multicolumn{7}{|c|}{ Ruminal digestibility, $\mathrm{kg} / \mathrm{kg}^{1}$} \\
\hline Dry matter & 0.77 & 0.79 & 0.76 & 0.67 & 1.424 & 0.733 \\
\hline Organic matter & 0.75 & 0.76 & 0.73 & 0.68 & 1.248 & 0.663 \\
\hline Crude protein & 0.72 & 0.66 & 0.67 & 0.75 & 1.694 & 0.345 \\
\hline Neutral detergent fiber & 0.95 & 0.94 & 0.91 & 0.95 & 2.954 & 0.665 \\
\hline
\end{tabular}

${ }^{1}$ Expressed relative to total digestible nutrients.

Means in the same row followed by different letters are significantly different $(\mathrm{P}<0.05)$ according to Tukey's test. 
the feeding of ruminants. The models are based on the synthesis of microbial protein in the rumen and on the rumen undegradable protein to meet the metabolizable protein requirement of the animal.

No alterations in the intakes of dry matter and nutrients were observed in the animals fed protein sources of different ruminal degradability, due to the similarity in the fibrous and non-fibrous carbohydrate contents of the diets, which enabled the maintenance of the microbial protein synthesis. The results of this study agree with Brito et al. (2007), who observed that cows fed different sources of true protein (soybean, cottonseed and canola meals) did not show differences in feed intake or digestibility. Contrarily, Brito and Broderick (2007) observed lower dry matter intake by cows fed urea than that of cows fed true protein (solvent soybean meal, cottonseed meal, or canola meal). It is possible that release of rumen degradable protein from urea was asynchronously relative to the dietary energy, and degradation of protein from solvent soybean meal, cottonseed meal and canola meal might have been more precisely relative to fermentation of the starch in the diet. The discrepancy between the results may not be simply explained by the source of dietary $\mathrm{CP}$, but rather by the fact that multiple factors such as diet composition, protein levels and type of experiment may affect DMI.

Besides the physical factors that may limit intake, there are also chemical factors (Huhtanen et al., 2008). Authors have reported increase in dry matter intake after postruminal protein infusion, indicating that part of the response is related to the metabolic effects, possibly mediated though improvements in the AA ratio and the energy in the tissue (Huhtanen et al., 2011). In addition, Clark et al. (1992) reported that the microbial protein is accountable for most of the total metabolizable AA to the small intestine. Thus, the results for microbial protein synthesis (Table 4) in this study indicate that the microbial AA that reached the intestine were similar in the different protein sources, which maintained the energy-intake requirement.

According to Allen (2000), VFA stimulate receptors present in the reticulo-rumen that activate satiety, reducing intake. The sensitivity of the epithelial receptors is proportional to the chain length; it is higher for butyrate, propionate and acetate, respectively, and the stimulus is higher at low $\mathrm{pH}$ values (Allen, 2000). Although the alteration of the protein sources resulted in difference in the proportion of butyric acid, the mean ruminal $\mathrm{pH}$ was above 6.0 at all sampling times due to the properties of the diet, which provided the same intake for NDF and non-fibrous carbohydrate, which resulted in similar production of propionic and acetic acids, i.e., there was no accumulation 
Table 4 - Effect of dietary source of protein (soybean meal (SM), cottonseed meal (CM), peanut meal (PM) and sunflower meal (SUM)) on balance nitrogen, efficiency of microbial synthesis and ruminal kinetics in crossbred Holstein $\times$ Gyr dairy heifers

\begin{tabular}{|c|c|c|c|c|c|c|}
\hline & \multicolumn{4}{|c|}{ Diets } & \multirow{2}{*}{ SEM } & \multirow{2}{*}{ P-value } \\
\hline & SM & $\mathrm{CM}$ & PM & SUM & & \\
\hline \multicolumn{7}{|l|}{$\mathrm{N}$ balance } \\
\hline $\mathrm{N}$ intake, $\mathrm{g} /$ day & 104.00 & 101.00 & 104.00 & 100.00 & 10.25 & 0.827 \\
\hline \multicolumn{7}{|l|}{ Fecal $\mathrm{N}$ excretion } \\
\hline g/day & 23.60 & 24.10 & 27.80 & 24.10 & 1.828 & 0.444 \\
\hline \multicolumn{7}{|l|}{ Urinary $\mathrm{N}$ excretion } \\
\hline g/day & 48.20 & 44.70 & 43.50 & 43.80 & 1.672 & 0.404 \\
\hline$\%$ intake & 46.30 & 44.20 & 41.80 & 43.80 & 1.208 & 0.326 \\
\hline \multicolumn{7}{|l|}{ Microbial N } \\
\hline g/day & 92.90 & 94.30 & 94.30 & 93.00 & 2.451 & 0.127 \\
\hline \multicolumn{7}{|l|}{ Microbial synthesis efficiency } \\
\hline $\mathrm{g}$ of microbial N/kg of TDN & 161.00 & 170.00 & 164.00 & 173.00 & 23.36 & 0.928 \\
\hline
\end{tabular}

TDN - total digestible nutrients.

Means in the same row followed by different letters are significantly different $(\mathrm{P}<0.05)$ according to Tukey's test.

of total volatile fatty acid or alteration of the degradation rate, which could cause changes in the $\mathrm{pH}$.

Despite the different degradability of the protein sources, the crude protein levels of the diets were similar, which was a decisive factor for the concentration of $\mathrm{NH}_{3}-\mathrm{N}$ in the rumen remaining similar. In all the evaluated protein sources, the average concentration of $\mathrm{NH}_{3}-\mathrm{N}$ remained above $5 \mathrm{mg} / \mathrm{dL}$, which, according Satter and Roffler (1975), has no effect on microbial protein production. The concentration of $\mathrm{NH}_{3}-\mathrm{N}$ in the rumen is a consequence of the balance between its production, absorption and utilization by microorganisms. The utilization efficiency of ammonia by the microorganisms for the microbial synthesis depends, among other factors, on the availability of energy in the rumen (Satter and Roffler, 1975), thus withstanding greater microbial growth (Russel et al., 1992).

The similarity in microbial $\mathrm{N}$ among the diets is possibly a reflection of the similar intake and digestibility of the nutrients, and of the similar $\mathrm{pH}, \mathrm{VFA}$ and $\mathrm{NH}_{3}-\mathrm{N}$ values, which allowed for similar substrates, ruminal environment and fermentation characteristics for microbial growth. The microbial protein synthesis efficiency remained similar with the different dietary sources of protein, because the fermentable energy available to ruminal bacteria influences their growth rate and, consequently, the quantity of ammonia converted to microbial protein. Conversely, Brito and Broderick (2007) found that ruminal concentration of $\mathrm{NH}_{3}-\mathrm{N}$ was greatest in the urea diet, but similar in the true protein sources. Although the $\mathrm{NH}_{3}-\mathrm{N}$ concentration did not differ among the protein sources, a numerical difference was observed, wherein a higher concentration of $\mathrm{NH}_{3}-\mathrm{N}$ was found for soybean meal and cottonseed meal than peanut meal and sunflower meal, suggesting that the degraded protein was rapidly utilized by microbiota in the formation of butyrate, which was also higher in soybean meal and cottonseed meal, the two protein sources with the greatest estimated ruminal degradations. No other significant effects of diet on ruminal VFA were detected.

Increase in the crude protein levels in a diet containing increasing amounts of rumen-degradable protein results in increased urinary excretion of $\mathrm{N}$ when it is not used for the synthesis of microbial protein if energy is limiting (Hristov et al., 2004). The rumen degradable protein can be converted to ammonia, absorbed through the rumen wall, detoxified to urea in the liver (Lobley et al., 1995) and largely lost in the urine (Choi et al., 2002). Whilst excess supply of $\mathrm{N}$ to the rumen is the main source for urea $\mathrm{N}$ excretion, it is not the only one. Inclusion of high levels of RUP shifts protein digestion to the small intestine, where it will be broken down to AA or remain undigested and pass to the feces. An imbalance of AA with greater supply than that required can also contribute to urea production. This fact did not occur in this study, because the protein digestibility and concentration of $\mathrm{NH}_{3}-\mathrm{N}$ did not differ among the protein sources, and urinary and fecal losses of $\mathrm{N}$ were similar among the diets; in other words, the sources do not modify the $\mathrm{N}$ excretion in the environment. Fecal $\mathrm{N}$ is primarily of microbial origin, with lower amounts of undegraded feed protein and endogenous secretions (NRC, 1985). Fecal N 
excretion can also be influenced by the site and extent of carbohydrate fermentation (Adams et al., 2004).

As observed, the total dry matter flow, passage rate and microbial $\mathrm{N}$ were similar among the true-protein sources. Agreeing with this result, Koenig and Beauchemin (2013) found that provision of rumen degradable and undegradable true protein sources did not affect the flow of dietary $\mathrm{N}$ from the rumen to the small intestine. On the other hand, Reynal and Broderick (2005) observed a linear increase in microbial $\mathrm{N}$ flow when the supply of rumen degradable true protein increased the dietary DM by $10.6-13.2 \%$. Brito et al. (2007), in turn, verified that higher supply of rumen-degradable protein was associated with increase in microbial $\mathrm{N}$ flow. However, the small variations observed in the composition of rumen-degradable protein from the diets with protein sources were not sufficient to change the flow, the passage rate and the microbial $\mathrm{N}$ in this study.

The effect of different sources of true protein in the diet was not significant as regards the microbial synthesis efficiency. It should be noted that in addition to the proportion of nutrients in the diet and the same sources of easily fermentable carbohydrates, other factors have been associated with the microbial synthesis efficiency, such as synchronization of the degradation of the feeds that make up the diet and greater supply of rumen-degradable protein (Calsamiglia et al., 2010).

In this study it was observed that the protein sources with different ruminal degradability associated with sugarcane provide the same digestibility conditions, resulting in efficient use of nitrogen, which is a key factor that determines the economic cost and the environmental impact of ruminant production systems.

\section{Conclusions}

Sugarcane can be supplemented with alternative protein sources to soybean meal in diets for heifers without modifying the fermentation parameters, microbial protein synthesis efficiency or nitrogen excretion in the environment.

\section{Acknowledgments}

The authors would like to thank Fundação de Amparo à Pesquisa do Estado de São Paulo (FAPESP) and Bellman Nutrição Animal for their financial support.

\section{References}

Adams, J. R.; Farran, T. B.; Erickson, G. E.; Klopfenstein, T. J.; Macken, C. N. and Wilson, C. B. 2004. Effect of organic matter addition to the pen surface and pen cleaning frequency on nitrogen mass balance in open feedlots. Journal of Animal Science 82:2153-2163.

Ahvenjärvi, S.; Vanhatalo, A.; Shingfield, K. J. and Huhtanen, P. 2003. Determination of digesta flow entering the omasal canal of dairy cows using different marker systems. British Journal of Nutrition 90:41-52.

Allen, M. S. 2000. Effects of diet on short-term regulation of feed intake by lactating dairy cattle. Journal of Dairy Science 83:1598-1624.

AOAC - Association of Official Analytical Chemists. 1990. Official methods of analysis. 15th ed. Association of Official Analytical Chemists, Washington, DC.

Brito, A. F. and Broderick, G. A. 2007. Effects of different protein supplements on milk production and nutrient utilization in lactating dairy cows. Journal of Dairy Science 90:1816-1827.

Brito, A. F.; Broderick, G. A. and Reynal, S. M. 2007. Effects of different protein supplements on omasal nutrient flow and microbial protein synthesis in lactating dairy cows. Journal of Dairy Science 90:1828-1841.

Broderick, G. A.; Brito, A. F. and Olmos Colmenero, J. J. 2007. Effects of feeding formate-treated alfalfa silage or red clover silage on the production of lactating dairy cows. Journal of Dairy Science 90:1378-1391.

Calsamiglia, S.; Ferret, A.; Reynolds, C. K.; Kristensen, N. B. and Van Vuuren, A. M. 2010. Strategies for optimizing nitrogen use by ruminants. Animal 4:1184-1196.

Clark, J. H.; Klusmeyer, T. H. and Cameron, M. R. 1992. Microbial protein synthesis and flows of nitrogen fractions to the duodenum of dairy cows. Journal of Dairy Science 75:2304-2323.

Cecava, M. J.; Merchen, N. R.; Gay, L. C. and Berger, L. L. 1990. Composition of ruminal bacteria harvested from steers as influenced by dietary energy level, feeding frequency, and isolation techniques. Journal of Dairy Science 73:2480-2488.

Choi, C. W.; Vanhatalo, A.; Ahvenjarvi, S. and Huhtanen, P. 2002. Effects of several protein supplements on flow of soluble nonammonia nitrogen from the forestomach and milk production in dairy cows. Animal Feed Science and Technology 102:15-33.

Czerkawski, J. W. 1986. Degradation of solid feeds in the rumen: spatial distribution of microbial activity and its consequences. p.158-172. In: Control of digestion and metabolism in ruminants. Milligan, L. P.; Grovum, W. L. and Dobson, A., eds. Prentice Hall, Englewood Cliffs, NJ, USA.

Erwin, E. S.; Marco, G. J. and Emery, E. M. 1961. Volatile fatty acid analyses of blood and rumen fluid by gas chromatography. Journal of Dairy Science 44:1768-1771.

Faichney, G. J. 1975. The use of markers to partition digestion within the gastrointestinal tract of ruminants. p.277-291. In: Digestion and metabolism in the ruminant. McDonald, I. W. and Warner, A. C. I., eds. University of New England Publishing Unit, Armidale, Australia.

Fenner, H. 1965. Method for determining total volatile bases in rumen fluid by steam distillation. Journal of Dairy Science 48:249-251.

Fox, D. G.; Tylutki, T. P.; Van Amburgh, M. E.; Chase, L. E.; Pell, A. N.; Overton, T. R.; Tedeschi, L. O.; Rasmussen, C. N. and Durbal, V. M. 2000. The Net Carbohydrate and Protein System for evaluating herd nutrition and nutrient excretion - The Cornell University Management Planning System. Department of Animal Science, Cornell University, Ithaca, NY. p.236.

Goering, H. K. and Van Soest, P. J. 1970. Forage fiber analyses (Apparatus, reagents, procedures, and some applications). Agriculture Handbook No. 379. ARS, USDA, Washington, D.C. 
Hoover, W. H. 1986. Chemical factors involved in ruminal fiber digestion. Journal of Dairy Science 69:2755-2766.

Hristov, A. N.; Etter, R. P.; Ropp, J. K. and Grandeen, K. L. 2004. Effect of dietary crude protein level and degradability on ruminal fermentation and nitrogen utilization in lactating dairy cows. Journal of Animal Science 82:3219-3229.

Huhtanen, P.; Rinne, M. and Nousiainen, J. 2008. Evaluation of the concentrate factors affecting silage intake of dairy cows; a development of the relative total diet intake index. Animal 2:942-953.

Huhtanen P.; Hetta, M. and Swensson, C. 2011. Evaluation of canola meal as a protein supplement for dairy cows: A review and a metaanalysis. Canadian Journal of Animal Science 91:529-543.

Ipharraguerre, I. R. and Clark, J. H. 2005. Impacts of the source and amount of crude protein on the intestinal supply of nitrogen fractions and performance of dairy cows. Journal of Dairy Science 88(E Suppl.):E22-E37.

Koenig, K. M. and Beauchemin, K. A. 2013. Nitrogen metabolism and route of excretion in beef feedlot cattle fed barley-based backgrounding diets varying in protein concentration and rumen degradability. Journal of Animal Science 91:2295-2309.

Lal, R. 2013. Managing soils and ecosystems for mitigating anthropogenic carbon emissions and advancing global food security. Bioscience 60:708-721.

Lanna, D. P. D.; Barioni, L. G.; Boin, C. and Tedeschi, L. O. 1999. RLM 2.0 - Feed for maximum profit, version 2.0. Piracicaba. (CD-ROM).

Lobley, G. E.; Connell, A.; Lomax, M. A.; Brown, D. S.; Milne, E.; Calder, A. G. and Farningham, D. A. H. 1995. Hepatic detoxification of ammonia in the ovine liver: Possible consequences for amino acid catabolism. British Journal of Nutrition 73:667-685.

NRC - National Council Research. 1985. Ruminant nitrogen usage. National Academy Press, Washington, DC.

Oliveira, S. G.; Berchielli, T. T.; Pedreira, M.; Primavesi, O.; Frighetto, R. and Lima, M. 2007. Effect of tannin levels in sorghum silage and concentrate supplementation on apparent digestibility and methane emission in beef cattle. Animal Feed Science and Technology 135:236-248.

Queiroz, M. F. S.; Berchielli, T. T.; Signoretti, R. D.; Ribeiro, A. F. and Morais, J. A. S. 2012. Metabolism and ruminal parameters of Holstein $\times$ Gir heifers fed sugarcane and increasing levels of crude protein. Revista Brasileira de Zootecnia 41:2101-2109.

Reynal, S. M. and Broderick, G. A. 2005. Effect of dietary level of rumen-degraded protein on production and nitrogen metabolism in lactating dairy cows. Journal of Dairy Science 88:4045-4064.
Reynolds, C. K. 2006. Splanchnic metabolism of amino acids in ruminants. p.225-248. In: Ruminant physiology: digestion, metabolism and impact of nutrition on gene expression, immunology and stress. Sejrsen, K.; Hvelplund, T. and Nielsen, M.O., eds. Wageningen Academic Publishers, The Netherlands.

Russell, J. B.; O’Connor, J. D.; Fox, D. G.; Van Soest, P. J. and Sniffen, C. J. 1992. A net carbohydrate and protein system for evaluation cattle diets. I. Ruminal fermentation. Journal of Animal Science 70:3551-3561.

Satter, L. D. and Roffler, R. E. 1975. Nitrogen requirements and utilization in dairy cattle. Journal of Dairy Science 58:1219-1237.

Sniffen, C. J.; O’Connor, J. D.; Van Soest, P. J.; Fox, D. G. and Russell, J. B. 1992. A net carbohydrate and protein system for evaluation cattle diets. II. Carbohydrate and protein availability. Journal of Animal Science 70:3562-3577.

Tempelman, R. J. 2004. Experimental design and statistical methods for classical and bioequivalence hypothesis testing with an application to dairy nutrition studies. Journal of Animal Science 82:E162-E172.

Uden, P.; Colucci, P. E. and Van Soest, P. J. 1980. Investigation of chromium, cerium and cobalt as markers in digesta. Rate of passage studies. Journal of the Science of Food and Agriculture 31:625-632.

Ushida, K.; Lassalas, B. and Jouany, J. P. 1985. Determination of assay parameters for RNA analysis in bacterial and duodenal samples by spectrophotometry influence of sample treatment and preservation. Reproducion Nutrition Development 25:1037-1046.

Van Soest, P. J.; Robertson, J. B. and Lewis, B. A. 1991. Methods for dietary fiber, neutral detergent fiber, and nonstarch polysaccharides in relation to animal nutrition. Journal of Dairy Science 74:3583-3597.

Vasconcelos, J. T.; Tedeschi, L. O.; Fox, D. G.; Galyean, M. L. and Greene, L. W. 2007. Review: Feeding nitrogen and phosphorus in beef cattle feedlot production to mitigate environmental impacts. Professional Animal Scientist 23:8-17.

Yang, J. Y.; Seo, J.; Kim, H. J.; Seo, S. and Ha, J. K. 2010. Nutrient Synchrony: is it a suitable strategy to improve nitrogen utilization and animal performance? Asian-Australasian Journal of Animal Science 23:972-979.

Wright, C. F.; Von Keyserlingk, M. A. G.; Swift, M. L.; Fisher, L. J.; Shelford, J. A. and Dinn, N. E. 2005. Heat- and lignosulfonate treated canola meal as a source of ruminal undegradable protein for lactating dairy cows. Journal of Dairy Science 88:238-243. 